\title{
Evaluation of the impact of compliance of precast discs of overlapping on the work of the frame of a multi-storey building
}

\author{
Nikolay Trekin ${ }^{1 *}$,Emil Kodysh ${ }^{2}$, Alexander Bybka ${ }^{2}$, Alexander Yamalov ${ }^{2}$ and Nikita \\ Konkov $^{2}$ \\ ${ }^{1}$ Moscow State University of Civil Engineering, Yaroslavskoe shosse, 26, Moscow, 129337, Russia \\ ${ }^{2}$ JSC «TSNIIPromzdany», 127238, 46, building 2, Dmitrovskoye Highway, Moscow, Russia
}

\begin{abstract}
The article provides an analysis and justification of the need to take into account the compliance of discs of overlapping and coatings when calculating frames from precast concrete structures. Previously conducted full-scale experiments showed that the rigidity of the precast overlapping with full filling of the seams, in comparison with the monolithic overlapping, decreases by 3-15 times due to the ductility of the joints. The use of refined computational models of structural solutions for frames, which take into account the compliance of the conjugations of elements, makes it possible to trace possible redistribution of efforts. Such an approach when reconstructing, it is possible to optimally select and calculate the enforcement of structure, and on new designing, to increase reliability and / or improve the economic performance of frame buildings. According to the results of analytical studies, formulas were adopted for the parameters that allow one to take into account the overall compliance of overlapping disks and coatings in computational models of building frames. Numerical studies on the computational model of a frame building made it possible to evaluate the effect of accounting for compliance on the stress-strain state of a multi-storey frame.
\end{abstract}

The constructive basis of multi-storey and one-storey buildings is a spatial carrier system of core and slab reinforced concrete elements interconnected to each other and ensuring the strength, stability and durability of the system as a whole, as well as its individual elements. The spatial work of the system is manifested in the fact that when one of its elements is loaded, other elements are included in the work, and the rigidity of buildings is largely ensured jointly by overlap disks and vertical diaphragms.

A characteristic feature of the buildings frameswork with precast concrete constructions is the presence of a large number of nodal mates. They, as a rule, depending on the adopted system of cutting the building into elements, are located in the most stressful areas. The joints of precast constructions have increased deformability due to a concrete deformation on the contact surfaces and cracking, compliance of welded joints of reinforcement and embedded parts. In addition, the compliance of the nodal mates increases with increasing stresses in them.

*Corresponding author: otks@narod.ru 
Precast overlap are the resource-demanding and responsible elements in multi-storey buildings that perform various important functions, such as the perception and transmission of vertical and gorizontal loads on the building skeleton, ensuring the spatial rigidity of the building, and also the function of enclosing structures for coating.

As horizontal stiffening diaphragms, which unite vertical supporting structures into a single spatial system, overlaps not only perceive and redistribute external loads, but also deforming in their own plane. Acting loads cause tensile or compressive forces in the elements of the overlapping discs; in addition, the single slabs of overlapping discs shift relative to each other. Also, due to the deformations in their own plane, they are the bending-shear and torsion connections between the vertical supporting structures.

The joint operation of precast slabs in the disks under external effect is ensured by monolithic seams between the slabs, along the side faces and the ends.

A large number of papers [1-4 and others] are devoted to research on this topic. Tests of full-scale fragments and models were carried out and, on the basis of dynamic tests, the rigidity of structures of existing buildings was indirectly determined. The studies conducted at the TSNIISK were among the first in this area [5-6].

According to the results of full-scale experiments, movements of precast discs of various designs were determined and it was shown that, in comparison with monolithic overlap, with full filling of seams the rigidity of the precast overlaps decreases 3-15 times due to the compliance of interfacing (depends on the design). According to the results, a method was developed for taking into account the reduction in rigidity by introducing a lower modulus of elasticity with a constant ratio between equivalent moduls a shear and elastic, equal to $G^{\prime} / E^{\prime}=0.35$ for monolithic overlaps and $G^{\prime} / E^{\prime}=0.15-0,25$ for precast overlaps. In this case, the coefficient of reduction of the modulus of elasticity of the precast overlap, $\mathrm{k}_{\mathrm{E}}=\mathrm{E}^{\prime} / \mathrm{E}_{0}$, which takes into account the reduction in the stiffness of the section due to the voids in the slabs and the compliance of the seams, is $0.1-0.6[7,8]$.

The considerable variation in values, especially for the coefficient of reduction of the modulus of elasticity, is explained, first of all, by the difference in the designs of the nodes of the overlaps considered.

The idealized calculation schemes used, for example, with hinged or rigid mating of overlap plates with beams, do not fully describe their real interactions. If the interfloor overlappings are assumed to be absolutely rigid, then the distribution of the horizontal load between the vertical bearing elements occurs in proportion to their flexural rigidity. In the case of their absolute flexibility, the distribution of the horizontal load occurs according to the cargo area. In real cases of frame working, the nature of the distribution of the horizontal load will be between these cases.

The use of refined computational models of construction solutions for frames, which take into account the compliance of the conjugations of elements, makes it possible to trace possible redistribution of efforts, as well as more adequately evaluate the magnitude and nature of their distribution in the supporting system of the building. Such an approach when reconstructing, it is possible to optimally select and calculate the enforcement of structure, and on new designing, to increase reliability and / or improve the economic performance of frame buildings.

A change in the compliance of overlapping discs leads to a change in their effect on the redistribution of forces between the vertical subsystems of frame buildings. The more rigid disk and its mates with vertical elements, the smaller the difference in horizontal displacements it allows, and with absolutely rigid disks all points of vertical constructions in the level of floors would have the same horizontal displacements.

Based on the results of comparative calculations of wall-frame symmetric buildings, it was found that reducing the stiffness of the precast discs with a reduced elastic modulus, adopted 15 times less than the same monolithic slab, leads to an increase in horizontal 
loads, perceived by the frames, for buildings $72 \mathrm{~m}$ long and $96 \mathrm{~m}$ by $15 \%$ and $20 \%$ respectively. At the same time, it was found that with sufficiently rigid overlapping disks there may be cases when the diaphragms in the level of the last floor are not supported, and the transverse frames are more addition loaded on account of the difference forms of horizontal frame displacements and diaphragms. When the overlap has compliance in its plane, this effect is not observed. Thus, accounting for the compliance of overlapping discs not only quantitatively but also qualitatively changes the redistribution of efforts between vertical subsystems.

Preliminary numerical studies of the work of the overlap cells and the coating on the plate-rod model developed for the finite element method [9], for the conditions of nonmonolithic seams between of plates under the action of a horizontal load in the plan of overlap showed that under the action of horizontal loads in the range of actual values of compliance, the cell deformation of the coating with compliant connections are 10-20\% more for a $6 \times 6 \mathrm{~m}$ cell than for a rigid disk, $14-30 \%$ for a $6 \times 12 \mathrm{~m}$ cell and $15-35 \%$ for a $6 \times 18 \mathrm{~m}$ cell [9]. With an increase in the number of steps of the cells along the length of the building, the cell deformation increases by more than 2 times compared with the hard overlap. With an increase in the number of spans, the deformations of the overlap in their plane also increase in comparison with one cell, but only slightly: by $0.5-5 \%$. Bending moments with a compliance disk overlap is also greater than with hard by $15-22 \%$. With an increase in the number of spans of a building from one to two, the increase in bending moments occurs slightly, within 5\%.

Using the example of calculating the precast bond frame of a 16-storey building, it has been revealed that the deformations of the compliance overlapping discs are 10-50\% higher than the rigid ones. And an increase in the displacement of columns, as is well known, entails an increase in the bending moments in them, that is, an increase in the eccentricity of the action of the vertical load on the columns.

To study the effect of the compliance of seams on the stress-strain state of constructive systems and to identify the most important factors, numerical studies were carried out on the frameworks of buildings of various floors for a horizontal unit load [10].

Currently, in order to take into account the compliance of mates in the calculation scheme of the finite element method (FEM), the actual seams between precast constructions are presented in the form of compliant elements, the geometric and stiffness parameters of which most correspond to the characteristics of real seams at various stages of the construction and loading of the building's bearing system. As such elements, typical rod and flat finite elements are used, as well as special elements that are available in the applied program.

The most fully stress-strain state of the precast overlap is described using a plate-rod model in which plates are modeled with flat finite elements, and concrete joints and welded joints are modeled as compliance joints. However, the dimension of the computational model with this representation increases significantly, which everywhere leads to errors in its formation and, as a result, to misinterpretation of the results. One of the goals of the presented work is, along with the study of the influence of the compliance of the nodal joints of overlap on the stress-strain state of the constructions of framework, to simplify the modeling of the conjugations of the overlap plates with the framework constructions with accounting to their compliance.

The authors carried out analytical studies of the techniques and justification of accounting for the compliance of joints using the equivalent rigidity coefficient. In the general case, the formula (1) was derived to determine the reduced rigidity coefficient by which the modulus of deformation of the plate material is multiplied [11]:

$$
K_{\text {red }}=\frac{a\left[3 b^{2}(1+\mu)+a^{2}\right] \cdot K_{Z}}{24 E_{0} I\left[1 / c_{d}+S^{2} /\left(c_{\mathrm{c}}(1+K)\right]\right.},
$$


where:

$a$ - is the calculated length of the overlap slab;

$b$ - is the width of the overlap slab;

$c_{c}$ - is the rigidity of compressed bonds;

$c_{s}$ - is the rigidity of the stretched bonds;

$c_{d}$ - is the rigidity of diagonal bonds;

$K=c_{s} / c_{c}-$ is the ratio parameter of the compliance of the stretched bonds to the compressed;

$E_{o}$ - modulus of elasticity of the overlap slab;

$S=(a+2 L) / b-$ parameter that takes into account the geometric characteristics of the plates;

$L-$ is the length of the plate;

$I-$ is the moment of inertia of the plate in its plane;

$K_{z}$ - coefficient taking into account the discrepancy the adopted final conditions of the theory of elasticity and FEM.

A series of calculations was carried out using the example of a six-story frame using several calculation schemes for horizontal loads. General view of the framework is shown in Figure 1. The characteristics of precast concrete elements and the magnitude of wind loads were taken on the basis of the recommendations of the 1.020-1/87 series.

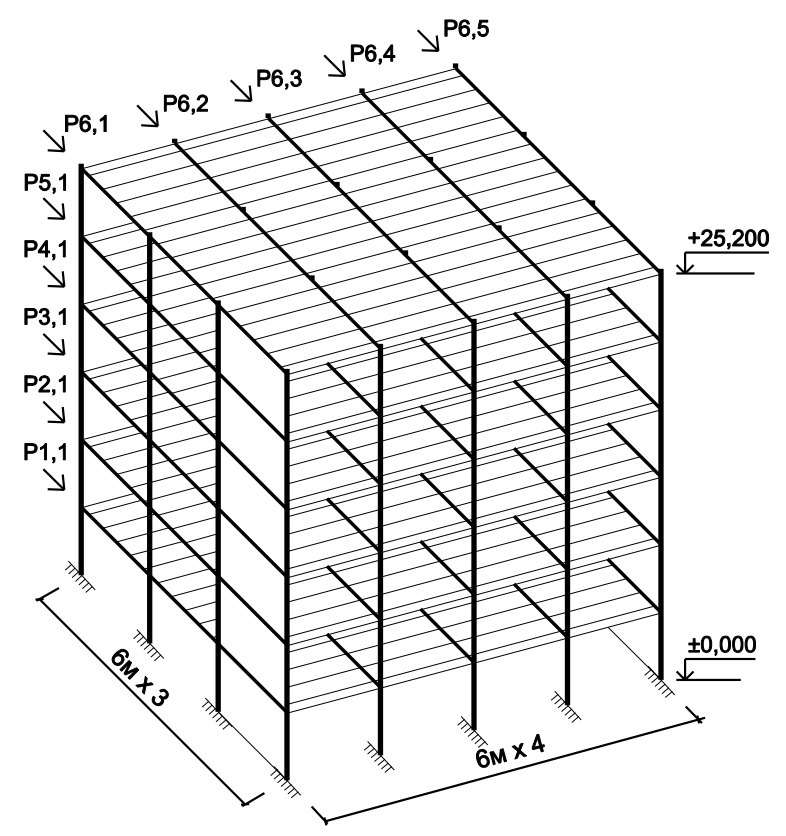

Fig.1. Fragment of the spatial framework

According to the first calculation scheme, articulated joints of columns with overlapping were taken, and the overlap itself was represented as solid plates with a reduced thickness of $0.13 \mathrm{~m}$. In the second calculation scheme, the compliance of the precast overlap in its plane was taken into account. According to the third scheme, in addition to the second scheme, partial restraint of the columns in the precast overlapping disk was taken into account.

The calculation results showed that taking into account the compliance of the overlapping discs leads to an increase in bending moments in the restraint of columns in the foundations for intermediate frames. For the adopted calculation scheme, the increase was 
from 14 to $18.3 \%$. In the middle frames, the bending moments in the columns on the edge of the basement decreased, and at the level of interfloor overlaps, they almost doubled. Compliance of the disk led to an increase in efforts in the diaphragms of the first floor and had practically no effect on the distribution of efforts in the elements of the overlying floors.

Partial restraint of the columns in the overlap discs significantly increases the bending moments in the level of interfloor floors. According to the example, the increase in bending moments in columns at the level of the third floor was five or more times. However, in absolute value, the bending moments in the columns at the level of interfloor overlappings are significantly lower than in the edge of the foundation.

The reduction of internal efforts in the communication panel with account a partial restraint is distributed in the following way: the minimum influence on the first floor level is $9 \%$ and the maximum on the upper floors is up to $47 \%$.

Figure 2 shows the diagrams of horizontal displacements measured at the level of interfloor overlaps for the extreme frame (frame-1), the first intermediate frame (frame-2) and the middle frame (frame-3), respectively.

a)

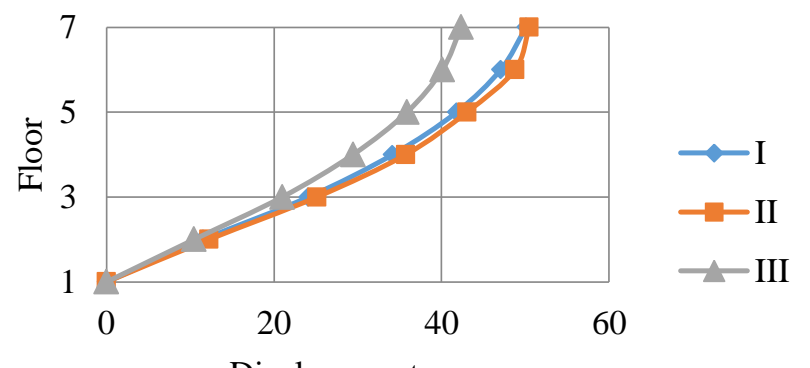

Displacements, $\mathrm{mm}$

b)

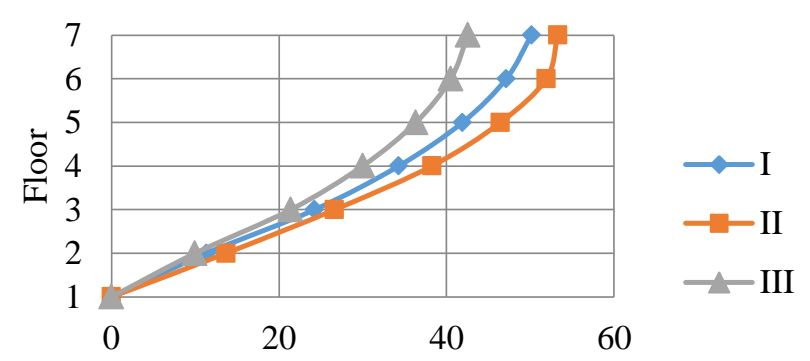

Displacements, mm

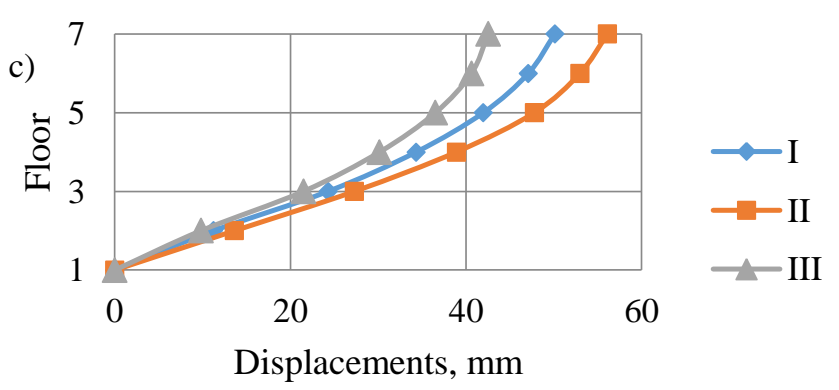

Fig. 2. Diagrams of frame displacements from horizontal load:

a) frame 1 ; b) frame 2 ; c) frame 3 ;I, II and III - numbers of frame calculation schemes 
As can be seen from the above diagrams, the consideration of disks compliance increased displacements in the middle frames by $11.3 \%$, and partial restraint reduced the deformation of the framework by $20 \%$. Thus, the total deformability of the framework decreased by $8.7 \%$.

Similar results were obtained in the study of frameworks of different dimensions and heights.

The considered approaches to accounting for compliance make it possible to reduce the laboriousness of work in creating calculation models of the finite element method and their dimension, which also minimizes the accumulation of errors in calculation models.

Taking into account the compliance of joints of precast overlapping discs in calculation models makes it possible to more accurately reproduce the actual operation of the building, thereby revealing the most loaded framework elements, which makes it possible to increase the reliability and durability of the building.

\section{References}

1. N.N. Skladnev, Issledovanie prostranstvennoy raboty rebristyh jelezobetonnyh paneley pokrytiy i perekrytiy na razlichnyh stadiyah napryajennogo sostoyaniya Avtoref. diss. na soisk uch. st. k.t.n. (Moskva, MISI im.V.V.Kuybysheva, 1969)

2. H.F. Asanbekov, Issledovanie raboty zamonolichennyh sbornyh jelezobetonnyh perekrytiy seysmostoykih jilyh zdaniy, $V$ knige Metody rascheta zdaniy i soorujeniy na seysmostoykost' (Moskva, Gosstroyizdat, 1958)

3. B.S. Vasil'kov, N.M. Volodin, Raschet Sbornyh Konstrukciy Zdaniy s Uchetom Podatlivosti Soedineniy (Moskva, Stroyizdat, 1985)

4. A.S. Zalesov, E.A. Chistyakov, Raschet i konstruirovanie monolitnyh karkasov s ploskimi perekrytiyami, Beton i jelezobeton №6, p.4-15 (1998)

5. S.V. Polyakov, Vliyanie jestkosti perekrytiy na raspredelenie usiliy mejdu nesuschimi vertikal'nymi i gorizontal'nymi konstrukciyami zdaniya, Beton i jelezobeton №8, p.4247 (1968).

6. S.V. Polyakov, K opredeleniyu usiliy $\mathrm{v}$ nesuschih elementah zdaniy pri deystvii gorizontal'nyh nagruzok, Stroitel'naya mehanika i raschet soorujeniy №2, p.12-14 (1962)

7. E.N. Kodysh, N.N. Trekin, I.K. Nikitin, Proektirovanie mnogoetajnyh zdaniy $s$ jelezobetonnym karkasom (Moskva: Izdatel'stvo Associacii stroitel'nyh vuzov, 2009)

8. N.N. Trekin, Rekomendacii po raschetu karkasov mnogoetajnyh zdaniy s uchetom podatlivosti uzlovyh sopryajeniy sbornyh jelezobetonnyh konstrukciy (Moskva: CNIIPromzdaniy, Associaciya «Jelezobeton», GUP CPP 2002)

9. E.N. Kodysh, N.N. Trekin, A.V. Bybka, K raschetu odnoetajnyh promyshlennyh zdaniy $\mathrm{s}$ uchetom prostranstvennoy raboty diskov pokrytiya, Sovremennye problemy sovershenstvovaniya raboty jeleznodorojnogo transporta Mejvuzovskiy sbornik nauchnyh trudov (Moskva RGOTUPS), p.306-311 (2004)

10. N.N. Trekin, Issledovaniya prostranstvennoy raboty uzlovogo sopryajeniya kolonny s perekrytiem, Mehanizaciya stroitel'stva №10, p.23-25 (2003)

11. N.N. Trekin, E.N. Kodysh, A.V. Bybka, D.A. Pimenov, Uchet podatlivosti diskov perekrytiya $\mathrm{v}$ prostranstvennyh raschetnyh modelyah, Budivel'ni konstrukciï: Mijvidomchiy naukovo-tehnichniy zbirnik naukovih prac' (budivnictvo) DP NDIBK Kiyv Vip. 74 Kniga 1, p.167-171 (2011) 